\title{
Sağlık Çalıșanlarında Enfeksiyon Riskleri ve Korunma: I. Kan ve Vücut Sıvıları Yoluyla Bulașan Enfeksiyonlar
}

\author{
Infection Risks for Healthcare Workers and Protection I: Infections Transmitted By Blood and Body Fluids
}

\author{
Emrah Salman, Zeynep Ceren Karahan
}

Sağlık calıșanlarının çalıștıkları ortamda maruz kaldıkları en önemli mesleki hastalık ve ölüm nedeni enfeksiyonlardır. Enfeksiyon etkenlerinin sağlık personeline bulașı en sık kan ve diğer vücut sıvilarıyla temas yolu ile olmaktadır. İkinci sırada solunum yolu bulașı yer alır. Kan ve diğer vücut sıvıları ile bulașan etkenler arasında sağlık çalıșanları açısından en önemli olanları hepatit B virüsü (HBV), hepatit C virüsü (HCV), insan immünyetmezlik virüsü (HIV) ve viral hemorajik ateș etkenleridir. Bunlar ve Mycobacterium tuberculosis gibi diğer bazı etkenler ile enfekte kadavralar, bu kadavralarla çalıșan Anatomi departmanı çalıșanları ve öğrenciler için de risk olusturmaktadır. Bu derlemede sağlık çalıșanlarına kan ve diğer vücut sıvıları ile bulașan enfeksiyon riskleri ile kadavra kaynaklı enfeksiyon etkenleri ele alınmıș ve bu risklerden korunma yollarına değinilmiștir.

Anahtar Sözcükler: Sağlık personeli, Enfeksiyon, Etyoloji, Eorunma.

The most important cause of occupational disease and mortality among healthcare workers is infections. Transmission of infectious agents to healthcare workers most frequently occurs via contact with blood and other body fluids. This is followed by respiratory transmission. The most important agents transmitted by blood and other body fluids to healthcare workers are hepatitis B virus (HBV), hepatitis $C$ virus (HCV), human immunodeficiency virüs (HIV) and viral haemorrhagic fever agents. Cadavers infected by these and some other agents such as Mycobacterium tuberculosis also possess a risk for Anatomy department staff and students. In this review, infection risks transmitted with blood and the other body fluids to healthcare workers and cadaver-related infectious agents are covered and ways of protection are briefly discussed.

Key Words: Healthcare worker, Infection, Ethiology, Protection.

Sağlık çalışanları, hasta bireyler veya bu bireylerin doku/organ/çıkartıları vb. ile temas zorunlulukları nedeniyle olduğu kadar içinde çalıştıkları ortamın özellikleri nedeniyle de diğer meslek mensuplarından farklı olarak bazı ek meslek risklerine sahiptir. Enfeksiyon etkenlerine, toksikkanserojen kimyasallara ve radyasyon, 1sı, gürültü, toz gibi fiziksel ajanlara maruziyet; kas-iskelet sistemini zorlayıcı çalışma şartları ve stres bu ek risklerden sadece birkaçıdır. Sağlık çalışanlarının çalıștıkları ortamda maruz kaldıkları en önemli mesleki hastalı ve ölüm nedeni enfeksiyonlardır. Sağlık çalışanında enfeksiyon riski; hastalığın toplumdaki yaygınlığına, toplumun bağışıklık durumuna, yeni bir suş yada etkenin ortaya çıkması gibi epidemiyolojik özelliklere, enfeksiyonun inkübasyon dönemi varlığ1 ve süresine, etkenin bulaşıc1lığ1 ve virülansı gibi etken özelliklerine ve koruyucu önlemlerin uygulanmas1, aşılanma öyküsü, altta yatan başka hastalık varlığ gibi bireysel faktörlere bağlıdır (1).

Enfeksiyon etkenlerinin sağllk personeline bulaşı en sık kan ve diğer vücut sivilariyla temas yolu ile olmakta, bunu solunum yolu bulașı izlemektedir. Sağlı çalışanları karşılaşılan enfeksiyon etmenleri açısından kendi içerisinde çeşitli risk gruplarına ayrılmakta, en riskli grubu laboratuvar çalışanları oluşturmaktadır. Sağlık çalışanlarının en sık karşılaştı̆̆ enfeksiyon etkenleri tablo 1'de verilmiştir (2). 
Tablo 1: Sağlık personelinde mesleki maruziyete bağlı önde gelen enfeksiyon riskleri

\begin{tabular}{|l|l|}
\hline \multicolumn{1}{|c|}{ Meslek } & \multicolumn{1}{c|}{ Enfeksiyon Etkenleri } \\
\hline Hekimler & Mycobacterium tuberculosis kompleks, HBV, HCV, HIV, SARS Coronavirus \\
\hline Diș hekimleri & HBV, HCV, HIV \\
\hline Hemșireler & $\begin{array}{l}\text { Metisiline dirençli Staphylococcus aureus (MRSA), Streptococcus pyogenes, Vankomisine dirençli enterokoklar } \\
\text { (VRE), Bordetella pertussis, Helicobacter pylori, Mycobacterium tuberculosis kompleks, Salmonella spp., CMV, } \\
\text { HAV, HBV, HCV, HEV, HIV, HSV, Human Parvovirus, Influenza virus, SARS coronavirus, Kızamık virüsü, Kabakulak } \\
\text { virusü, Rubellavirus, Varicella Zoster Virus }\end{array}$ \\
\hline $\begin{array}{l}\text { Laboratuvar } \\
\text { çalıșanları }\end{array}$ & $\begin{array}{l}\text { MRSA, Brucella spp., Salmonella spp., Shigella spp., Clostridium difficile, Bartonella hanselae, Coxiella burnettii, } \\
\text { Rhinovirus, Giardia lamblia }\end{array}$ \\
\hline
\end{tabular}

Laboratuvar ile ilişkili enfeksiyonlar (LIE), laboratuvar çalışanının semptomatik veya asemptomatik olduğuna bakılmaksızın laboratuvar veya laboratuvar ile ilișkili işlernedeniyle kazanılan enfeksiyonlardır. LİE, sağllk çalışanları arasında en az dikkat çeken, en nadir tartışlan, eksik rapor edilen hatta hiç rapor edilmeyen enfeksiyonlardır. Bunun en önemli nedeni, laboratuvar kazalarının siklıkla atlanmas1, önemsenmemesi veya alışılagelmiş olarak nitelendirilmesidir. Kazaların ve enfeksiyonlarin bildirimi ve laboratuvar çalışanının rutin sağlık kontrolleri yapılmadığı sürece LIE'nin gerçek insidansının belirlenmesi olanaksızdır (3). Yine de son 50 yılda aşağıdaki faktörlere bağlı olarak LIE sıklığında önemli azalma olduğu tahmin edilmektedir:

1. Laboratuvar kurulumundaki gelişmeler (mikrobiyolojik güvenlik kabinlerinin kullanımı, negatif basınçlı L-3 laboratuvarların yapilandirılması $\mathrm{vb})$,

2. LIE hakkında farkındalı̆̆ın artması ve biyogüvenlik kurallarına uyulmaya başlanmas1,

3. Profesyonel biyogüvenlik organizasyonlarının [Amerikan Biyogüvenlik Birliği (ABSA, 1984); Avrupa Biyogüvenlik Birliği (EBSA, 1996); Asya-Pasifik Biyogüvenlik Birliği (A-PBA, 2005) vb] kurulması ve biyogüvenlik konusunda profesyonel destek alınması.

Teorik olarak uygun şartlar sağlandığında ve gerekli önlemler alınmadiğında, hastada enfeksiyona yol açan hemen her etken sağlık çalışanına da bulaşma potansiyeline sahiptir. Bu enfeksiyon risklerinden korunmada kişisel önlemler kadar kurumsal ve yasal düzenlemeler de önemli rol oynar. Ülkemizde sağlık çalıșanlarında enfeksiyon riskini belirlemek, gerekli önlemleri almak ve tedavisini sağlamak üzere yasal düzenlemeler yapilmaktadır. Yataklı tedavi kurumlarında sağlık hizmetleri ile ilișkili olarak gelișen enfeksiyon hastalıklarını önlemek ve kontrol altına almak, konu ile ilgili sorunları tespit etmek, çözümüne yönelik faaliyetleri düzenleyip yürütmek ve yataklı tedavi kurumları düzeyinde alınması gereken kararları gerekli mercilere iletmek üzere, enfeksiyon kontrol komitesi olușturulmasını tanımlayan ve bu komitenin çalışma şekli, görev, yetki ve sorumluluklarına ilișkin usul ve esasları düzenleyen "Yatakl1 Tedavi Kurumlar1 Enfeksiyon Kontrol Yönetmeliğii", 11.8.2005 tarih ve 25903 sayll Resmi Gazetede yayınlanarak yürürlüğe girmiştir. Sağlık kuruluşlarında risk değerlendirmesi, 29.12.2012 tarih/ ve 28512 sayll Resmi Gazete'de yayımlanan "İş Sağlığ1 ve Güvenliği Risk Değerlendirmesi Yönetmeliği”"nde yer alan hükümler doğrultusunda yapılmaktadır. Çalışma ve Sosyal Güvenlik Bakanlığ1 tarafindan hazirlanan ve 15.06.2013 tarih ve 28678 sayl1 Resmi Gazetede yayımlanan, "Biyolojik Etkenlere Maruziyet Risklerinin Önlenmesi Hakkındaki Yönetmelik”, çalışanların ișyerindeki biyolojik etkenlere maruziyetinden kaynaklanan veya kaynaklanabilecek sağlık ve güvenlik risklerinin önlenmesi ve bu risklerden korunulmasına dair asgari hükümleri düzenlemektir. Tüm bu düzenlemelere rağmen, ulusal meslek hastalıkları istatistisklerine sağlı çalışanlarına ait yaralanma ve hastalık bilgileri genellikle yansımamakta ya da sadece iş sağlı̆̆ı birimi olan ve düzenli kayıt tutan oldukça az sayıdaki hastaneden bildirimler yapilmaktadir. Yediyüzbini aşkın sağlık çalıșanının olduğu Türkiye'de en iyi koşullarda yılda 20 bin iş kazası bildirimi ve üç bin meslek hastalığ1 tanısı konulması beklenirken Sosyal Güvenlik Kurumunun 2012 verilerine göre iş kazas1 bildirimlerinin sayıs1 131, meslek hastalığı tanısı ile kayıt altına alınan sağlık çalışanı sayısı ise sadece beştir (4).

Bu derlemede, sağlık çalıșanlarına kan ve diğer vücut sıvıları yoluyla en sık bulaşan enfeksiyon etkenleri ile kadavra kaynaklı enfeksiyonlar ele alınacak ve bulaștan korunmak için alınması gereken önlemler üzerinde durulacaktır.

\section{Sağlık Çalıșanlarına Kan ve Diğer Vücut Sıvıları Yoluyla Bulașan Enfeksiyon Erkenleri}

Kan ve diğer vücut sıvıları ile bulașan etkenler arasında sağlık çalışanları açısından en önemli olanları hepatit B virüsü (HBV), hepatit $C$ virüsü $(\mathrm{HCV})$, insan immün yetmezlik virüsü (HIV) ve viral hemorajik ateş etkenleridir. $\mathrm{Bu}$ etkenler sağllk çalıșanlarında önemli morbidite ve mortalite nedenidir. Sağlık çalışanına enfeksiyon bulası en sık kesici veva delici aletler ile perkütan yaralanma sonucu gerçekleşmektedir. Perkütan yaralanma özellikle enjeksiyon, kan alma, iğne başlı̆̆ının kapatılması, iğnelerin atım işlemleri, kirlilerin ve atık malzemelerinin taşınması, kan ve vücut sıvilarının enjektörden tüplere 
aktarımı gibi işlemler sırasında gerçekleşmektedir. En sik bildirilen yaralanma nedeni, iğne başliğının yeniden kapatılmasıdır (5).

Yaralanmaların \%90’1 gelișmekte olan ülkelerden bildirilmektedir. Avrupa'da her yıl yaklaşık 304.000 sağlık çalışanında HBV, 149.000 sağlık çalışanında HCV, 22.000 sağlık çalışanında HIV ile kontamine materyalle perkütan yaralanma meydana gelmektedir (6). Türkiye'de yapılan çalışmalarda sağlık çalışanlarının yaklaşık üçte ikisinin meslek yaşamları boyunca en az bir kere kaza sonucu hastalarin kan veya vücut sıvilarına temas ettikleri bildirilmiştir (5). Tüm dünyada tahmini 35 milyon sağlık çalışanı mevcuttur ve kesici-delici alet ile yılda yaklașı üç milyon yaralanma olayı olmaktadır. Dünya genelindeki sağlık çalışanlarında, perkütan mesleki maruziyet için atfedilen risk oranları HBV, HCV ve HIV için sirasiyla \%37, \%39 ve \%4,4’tür.Dünya Sağllk Örgütü (DSÖ) 2002 raporuna göre tüm dünyadaki sağlık çalışanları, yılda en az bir kere enfekte kan ve vücut siviları ile perkütan temas etmektedir. Bu materyallerin yaklaşık iki milyonunun HBV, 900 bininin HCV, 120 bininin ise HIV ile kontamine olduğu belirtilmiştir. Tanımlanan yaralanmaların neticesinde yılda yaklaşık 66.000 sağlık çalışanında HBV, 16.000 sağlık çalışanında HCV ve 200-5000 sağlık çalışanında HIV enfeksiyonu oluşmaktadır. Kontamine iğneden perkütan yaralanma sonucu enfeksiyon gelişme riski HBV için \%2-40, HCV için \%3-10, HIV için \%0-3'dür (7).

\section{Hepatit B Virüsü(HBV)}

HBV, sağlık çalışanına bulaş riski en yüksek olan enfeksiyon etkenidir. Endemik bölgede sağlik çalışanlarının ortalama \%1'i bir yıl içinde HBV enfeksiyonu geçirmektedir. Bir cerrah için tüm çalışma hayatı boyunca (40 y1l) HBV ile enfekte olma riski $\% 50$, semptomatik HBV enfeksiyonu geçirme riski \%20, HBV'ye bağlı kronik karaciğer hastalığ1 gelişme riski ise $\% 5$ olarak tahmin edilmektedir (8).

HBV bulaşı için 0,0001 $\mathrm{ml}$ enfekte plazma bulaşı yeterlidir. Kan ve kan ürünleri, tükürük, beyin omurilik sivis1 (BOS); periton, perikard, sinovya ve amniyon siviları, semen ve vajinal sekresyonlar, dokular, organlar ve kan içeren herhangi bir vücut sıvısı HBV bulaşına sebep olabilir. Kan, serum, yara eksüdası, BOS, plevra ve periton sıvılarının enfeksiyözitesi yüksektir. Semen, vajinal sekresyon, tükürügün enfeksiyozitesi orta düzeyde; idrar, feçes, ter, gözyaşı gibi vücut salgilarının enfeksiyözitesi ise çok düşüktür. Perkütan temas HBV geçişi açısından en etkili yol olsa da sağlık çalışanları arasında HBV bulaşı açısından küçük bir bölümü oluşturur. Sağlık çalışanları açısından çok daha önemli olan bulaş yolu çevresel kontaminasyondur (8). HBV kuru kanda, oda sicaklığında bir hafta enfeksiyöz kalabilmektedir. Bu durum özellikle hemodiyaliz ünitelerinde çalışan sağlık ekibine HBV bulaşma riskini artıran önemli bir faktördür. Perkütan yaralanma öyküsü olmayan sağlık çalışanlarında bütünlüğü bozulmuş deri ya da mukozadaki lezyonlardan kontamine yüzeylere temas sonucu $\mathrm{HBV}$ bulaşının gerçekleşebileceği unutulmamalidir (9).

Riskli maruziyet sonrasında klinik hepatit B enfeksiyonu gelişme riski, yaralanma ciddiyetine, temas edilen kan miktarı ve kandaki viral yük düzeyine, kaynak kişin $\mathrm{HBs} \mathrm{Ag}$ ve HBe Ag seropozitifliğine ve sağlik personelinin aşılı olup olmamasina göre değişmektedir. Hasta kanında HBs $\mathrm{Ag}(+), \mathrm{HBe} \mathrm{Ag}(+)$ ise enfekte iğne ile perkütan yaralanma sonras1 sağlık çalışanında klinik hepatit görülme oranı \%22-31, serokon versiyon oran1 \%37-62 iken hastada HBs $\mathrm{Ag}(+)$, $\mathrm{HBe} \mathrm{Ag}(-)$ ise klinik hepatit görülme oran1 $\% 1-6$, serokon versiyon oran1 \%23-37'dir (8). Aşılanmamış bireylerde herhangi bir kesici delici yaralanma sonras1 HBV bulaşma riski \%6-30 arasındadır(10).

Ülkemizde yapılan çeşitli çalışmalarda, toplumda $\mathrm{HBs} \mathrm{Ag}$ prevalans1 ortalama $\% 5 \quad(\% 3,9-\% 12,5)$; sağlik çalışanlarında $\quad \mathrm{HBs} \quad \mathrm{Ag}$ pozitifliği \%2,4-5,4, doğal bağışılklık oranlar1 \%15-35, aşılı bağışıklık oranlar1 \%41-75,7 arasinda bildirilmiştir (10-12). Y1llara göre değerlendirildiğinde, 1989-1999 y1lları arasında sağlık personelinde HBV taşıyıcıllık oran1 \%4,8 iken 2000-2005 y1llar1 arasında \%2,19 bulunmuştur (13). Bu azalmada aşılama programlarının önemli etkisi olmuştur. Hepatit B aşıs1 1982 y1lından beri uygulanmakta olup, 1987 yllından itibaren sağlik personelinin aşılanmasına başlan- mıştır. Sağlık çalışanları yanında sağlık eğitimi veren tıp, diş hekimliği vb. fakültelerin öğrencilerini de aşılama kapsamına alan genişletilmiş aşılama programına 2009 tarihinde geçilmiştir (10).

HBV bulaşının önlenmesinde en etkili yol aşılamadır. Aşı uygulamasının, HBV bulaşını \%90-\%95 oranında önlediği bildirilmektedir (14). Aşının zorunlu, ücretsiz ve kolay ulaşılabilir olması aşılanma oranlarının artmasinda etkilidir. Hepatit B bulaşının engellenmesinde aşılama yanında maske, eldiven, gözlük gibi kişisel koruyucu donanım kullanımı, invaziv ișlemlerde mümkün olduğunca tek kullanımlık malzemelerin kullanılması, atıkların uygun kaplarda ve koşullarda uzaklaşt1rilması ve personeli bilgilen-dirmeye yönelik düzenli ve sürekli hizmet-içi eğitim programlarının organizasyonu da önemlidir (16).

Hepatit B enfeksiyonu prevalansının \%30 ve üzerinde olduğu toplumlarda sağlık çalışanlarına aşılama öncesi HBV ile karşıllaşma durumunu gösteren serolojik testler yapilabilirse de rutinde böyle bir uygulama gerekli değildir. Aşılanan sağlık personeli üç doz aşının tamamlanmasindan 1-2 ay sonra anti-HBs antikoru oluşumu yönünden test edilmelidir. Üç doz aş1 sonras1 $10 \mathrm{mIU} / \mathrm{mL}$ düzeyinde antiHBs antikor düzeyi sağlandığ1 takdirderapel dozlara ya da antikor titrelerinin izlenmesine gerek yoktur. Așlama ile sağlanan antikor düzeyi sekiz yılda başlangıç titresinin $\%$ 40'ına, 12 yılda ise aşılananların \%60'ında ölçülebilir düzeyin altına inmektedir. Ancak bu durumda da aşının koruyuculuğunun devam ettiği kabul edilmektedir. Üç doz aşı ile yeterli antikor yanıtı oluşturamayanlara ikinci üç dozluk uygulama yapilır, bunda da yeterli antikor yanitı sağlanamazsa kişi aşıya yanıtsız kabul edilir. Bu durumda eğer daha önce bakılmamış ise bu kişilerin $\mathrm{HBV}$ taşıyıcısı olup olmadiğı araştırılmalıdır. Aşıya yanıtsız bireylere riskli temas sonrasinda bir ay ara ile iki kez Hepatit B hiperimmun globulin (HBIG) uygulanması tavsiye edilmektedir (16).

İğne batması, mukoza ya da göze enfekte materyal sıçraması gibi yüksek riskli bir temas sonrasinda profilaksiye 
karar verirken kaynak kişinin $\mathrm{HBV}$ enfeksiyonu durumu ve temas eden sağlık personelinin aşılanma durumu dikkate alınmalıdır. Daha önceden aşı1ı ve bağışık yanıtı olan sağlık personelinde kaynağın durumu ne olursa olsun hiçbir tedaviye gerek yoktur. Ancak kaynak kişi $\mathrm{HBsAg}$ pozitif ve temas eden sağlık personeli aşısız ise temas sonrası ilk yedi gün, tercihen ilk 24 saat içinde, HBIG uygulanmalı ve Hepatit B aşısının ilk dozu ile birlikte aşı takvimi başlatılmalıdır. Temastan yedi günden sonra yapılan başvurularda sağlık personeline HBIG uygulanmamalidır. Temas sonrası profilaksi şeması tablo 2'de görülmektedir (17)

\section{Hepatit C Virüsü (HCV)}

Hepatit C virüsü için en önemli bulaş yolu iğne batması veya keskin aletlerle yaralanmadır. Mukozal membranlara ve konjunktivaya enfekte kanin sıçraması ile de bulaş gerçekleşebilir. Bütünlügü bozulmamış deri ile kan temas1 sonucunda HCV'nin bulaştığına dair rapor yoktur (15). Yapılan bir çalışmada; serumda $\mathrm{HCV}$ RNA saptanan hastaların \%32'sinin tükürügünde, \%57'sinin semeninde, $\% 22$ 'sinin vajinal sekresyonunda HCV RNA tespit edilmiştir(18). Perkütan yaralanma sonucu $\mathrm{HCV}$ pozitif bir kaynaktan virüs bulaşına bağlı serokonversiyon oranı ortalama olarak \%1,8'dir (\%0-7) (19). Arter veya ven içerisindeki geniş lümenli aletlerle derin yaralanmalar gibi yüksek riskli yaralanmalarda bu oran $\% 6,7$ iken yüzeyel yaralanmalar gibi düşük riskli yaralanmalarda $\% 0,009$ 'dur (20). Hepatit C virüsü oda sıcaklığında çevresel, yüzeylerde, dört güne kadar enfektivitesini koruyabilmektedir (21). Hepatit B'nin aksine, hemodiyaliz ortamları hariç, HCV'li kan ile çevresel kontaminasyon anlaml ${ }^{\text {bir }}$ enfeksiyon kaynağı değildir (22).

Sağlık çalışanları arasında yapılan araştırmaların çoğunda anti-HCV pozitiflik oranları normal popülasyonla benzerlik göstermektedir. Türkiye'de yapilan çalışmalarda anti-HCV pozitiflik oranlar1 genel popülasyonda \%0-3; sağlık çalışanlarında \%0-2,9 (ortalama $\% 0,83$ ) arasında bulunmuştur (23). Sağlık çalışanlarında rutin olarak antiHCV bakılması önerilmemektedir(24).

Mesleki maruziyet sonucu HCV geçişi için en önemli risk faktörleri büyük damar girişimleri sırasında yaralanma, derin yaralanma, erkek cinsiyet ve kaynak hastadaki viral yüktür. Viral yük $>106$ kopya/mL olan hastalardan HCV bulaş riski, viral yükü<104 kopya/mL olanlara kiyasla 11 kat daha fazladir (20).

HCV şüpheli temas sonrasında sağlık çalışanlarında profilaksi önerilmemektedir (25). Temas sonras1 öncelikle temas eden kişinin ve mümkünse kaynağın anti-HCV antikoruna bakılmalıdır. Temas eden kişide ayrıca bazal ALT düzeyi bakılmalıdır. Kaynak anti-HCV pozitif ise sağlık çalışanı $\mathrm{HCV}$ yönünden takip edilmeli, 4-6 ay sonra anti-HCV ve ALT testleri tekrarlanmalıdır. İmkân varsa erken tanı için temastan 4-6 hafta sonra HCV RNA bakilması önerilmektedir. Kaynak ve temas eden kişide tespit edilen Anti-HCV pozitiflikleri mutlaka RIBA veya kalitatif $\mathrm{HCV}$ RNA tayini ile doğrulanmalıdır. (26). HCV için tanısal testlerin ortalama yükselme zamanlarıve testlerin zamana göre duyarlilikları tablo 3'te belirtilmiştir (27). Avrupa ülkelerinde riskli temas sonrasinda sağlık çalışanında dört ay süresince aylık ALT takibi ve altınc1 ayda anti-HCV bak1lmas1; izlem esnasinda ALT yükselir veya anti-HCV pozitifleşirse HCV-RNA bakılması önerilmektedir. Amerika Birleşik Devletleri'nde temas sonrasinda periyodik izlemde dört ve altınc1 aylarda ALT ve anti-HCV takibi yapilmakta, anti-HCV pozitileşirse HCV-RNA bakilmaktadir (28). Enfeksiyonun erken tanisı ve tedaviye erken başlanması kronikleşmenin önüne geçilmesi açısından önemlidir. Interferon ile antiviral tedavi temas sonras1 8-12. haftalarda başlatılırsa kronikleşmeyi önlemektedir (29). Bu nedenle temastan sonra 4-6.haftada HCV-RNA testi ile takip, erken tanı ve zamaninda tedaviye olanak vermesi ve maliyet-etkin bir yöntem olması nedeniyle tercih edilebilir.

Tablo 2: Sağlık personelinde Hepatit B virüsü için temas sonrası profilaksi şeması

\begin{tabular}{|c|c|c|c|}
\hline \multirow{2}{*}{$\begin{array}{l}\text { Temas eden } \\
\text { personel }\end{array}$} & \multicolumn{3}{|c|}{ Kaynak } \\
\hline & HBsAg negatif & HBsAg pozitif & Bilinmiyor \\
\hline Așılanmamıș & HBV așı șeması bașla & 1 doz HBIG + HBV așı șeması bașla & HBV așı șeması bașla \\
\hline Așılı-Yanıt var & Tedaviye gerek yok & Tedaviye gerek yok & Tedaviye gerek yok \\
\hline Așılı-Yanıtsız & Tedaviye gerek yok & $\begin{array}{l}2 \text { doz HBIG VEYA } \\
1 \text { doz HBIG + HBV așı șeması bașla }\end{array}$ & $\begin{array}{l}\text { Yüksek riskli kaynak ise } \\
\text { HBsAg pozitif kaynak gibi davran }\end{array}$ \\
\hline $\begin{array}{l}\text { Antikor yanıtı } \\
\text { bilinmiyor }\end{array}$ & Tedaviye gerek yok & $\begin{array}{l}\text { Temas eden kișide Anti-HBs antikor titresine bak: } \\
\geq 10 \mathrm{mIU} / \mathrm{mL} \rightarrow \text { tedaviye gerek yok } \\
<10 \mathrm{mIU} / \mathrm{mL} \rightarrow 1 \text { doz HBIG }+ \text { HBV așı șeması } \\
\text { bașla }\end{array}$ & $\begin{array}{l}\text { Temas eden kișide Anti-HBs antikor titresine bak: } \\
\geq 10 \mathrm{mlU} / \mathrm{mL} \rightarrow \text { tedaviye gerek yok } \\
<10 \mathrm{mlU} / \mathrm{mL} \rightarrow \text { tekrar HBV așı șeması bașla, yüksek } \\
\text { riskli kaynak ise } 1 \text { doz HBIG ekle }\end{array}$ \\
\hline
\end{tabular}

Tablo 3: HCV RNA,Anti-HCV pozitifleşmeve ALT düzeylerinde yükselme zamanları ve zamana dayalı test duyarlılıkları

\begin{tabular}{|l|l|l|l|}
\hline Gösterge & Ortalama süre & 1.ay duyarlıı̆ı \% & 6.ay duyarlıı̆ı \% \\
\hline HCV RNA pozitifliği & 10.gün (2-3 hafta) & 100 & 100 \\
\hline Anti-HCV pozitifliği & 66. gün (4-10 hafta) & $10,2(3,3-18,8)$ & 100 \\
\hline ALT yükselmesi & 40. gün & $36,8(36,8-44,43)$ & $93,6(93,6-100)$ \\
\hline
\end{tabular}




\section{İnsan İmmün Yetmezlik Virüsü (HIV)}

Tüm dünyada her yıl sağlık çalışanlarının $\%$ 0,5'inin mesleksel maruziyet sonucu HIV ile karşılaştığı ve her yıl 1000 yeni HIV enfeksiyonu geliştiğ tahmin edilmektedir (30).

HIV bulaşı açısından enfeksiyöz kabul edilen örnekler kan, doku örnekleri, semen, vajinal sekresyonlar ve steril vücut sivilardır (BOS, plevra, periton, perikart, sinoviya ve amniyon sivis1 vb). Gözle görünür düzeyde kan içermedikçe dışkı, burun salgıları, tükürük, balgam, ter, idrar ve kusmuğun enfeksiyöz olmadığı kabul edilmektedir (31).

Kan ve diğer enfeksiyöz vücut sıvılarına maruziyet sonrası sağlık çalışanında HIV enfeksiyonu gelişme riski temasin niteliği ve hastalığin evresine bağlıdır. Temas edilen örneğin ne olduğu, örneğin kan içerip içermediği, örneğin miktarı, temasta aracılık eden gereçler (lümenli-lümensiz olması, kanla bulaşık olup olmaması vb) ve temasin düzeyi (derin-yüzeysel), temasın niteliğini tanımlayan faktörlerdir. HIV ile enfekte kişinin kanıyla perkütan ve mukozal temas sonrası bulaş riskleri sırasıyla $\% 0,3$ ve $\% 0,09$ 'dur. Bütünlüğü bozulmuş deri ile enfekte örneğin teması sonrasında bulaş riskinin $<\% 1$ olduğu tahmin edilmektedir. Kaynak hastada viremi başlangıcı ile anti-HIV antikorlarının saptanabilir düzeye ulaşması arasındaki pencere döneminin atlanmas1 teorik olarak sorun oluşturabilirse de, kaynak hastada güvenilir bir HIV ELISA testinin sonucu negatif ise, hasta HIV enfeksiyonu açısından risk faktörlerine sahip değilse ve hastanın klinik bulguları akut HIV enfeksiyonunu düşündürmüyorsa bulaş riski olmadığı kabul edilir (32). Bununla birlikte, düşük plazma HIV RNA titresi bulaş olasıllı̆̆nı dişlamamakta, saptanamayacak kadar düşük titrede HIV RNA taşıyan kaynak hastalardan bile bulaş olabilmektedir. Kaynak hastanın temastan sonraki 60 gün içinde HIV enfeksiyonu nedeniyle ölmesi bulaş riskini arttıran önemli bir faktör olarak kabul edilmektedir $(32,33)$.

Sağlık personelinin HIV ile karşılaşması durumunda, deri su ve sabun ile, göz steril serum fizyolojik ile, ağız ve burun ise suyla iyice yıkanmalıdır. HIV bulaş riski taşıyan bir yaralanmadan sonra sağlık çalışanına temas sonrasi profilaksi mümkün olan en k1sa sürede (ideal olarak temastan sonraki ilk bir saat içinde) tablo 4 ve tablo 5'te özetlenen kriterler göz önüne alınarak uygulanmalıdır. Temastan sonra dördüncü hafta, üçüncü ve altıncı aylarda sağlık personelinin HIV antikor testleri tekrarlanmalıdır. Serokonversiyon genellikle ilk üç ayda gözlenir, altıncı aydan sonra gecikmiş serokonversiyonson derece nadirdir (34).

Tablo 4: Perkütan yaralanma sonrasında HIV profilaksisi

\begin{tabular}{|l|l|l|l|l|}
\hline \multirow{2}{*}{ Temas Niteliği } & \multicolumn{4}{|c|}{ Kaynak } \\
\cline { 2 - 5 } & HIV (+) / 1. Sınıf & HIV (+) / 2. Sınıf & HIV durumu bilinmiyor & HIV (-) \\
\hline Hafif $^{3}$ & 2 ilaç ile TSP* & $\geq 3$ ilaç ileTSP & TSPönerilmez $\dagger$ & TSPgerekmez \\
\hline Yoğun $^{2}$ & $\geq 3$ ilaç ileTSP & $\geq 3$ ilaç ileTSP & TSPönerilmez $\dagger$ & TSPgerekmez \\
\hline
\end{tabular}

* TSP:Temas sonrası profilaksi

† Yüksek riskli kaynaktan maruziyetsözkonusuysa iki ilaç ile TSP verilebilir

1 Lümensiz iğne ile veya yüzeysel yaralanma

2 Genișlümenli iğne ile yaralanma, derin dokuya batma, kesici-delici aletin yüzeyinde görünür kan olması, iğnenin hastanın arter veya venine girmek için kullanılmıș olması.

3 Asemptomatik HIV enfeksiyonu veya düșük viral yük düșük(<1500 kopya/ml)

4 Semptomatik HIV enfeksiyonu, AIDS, akut serokonversiyon, yüksek viral yük ( $\geq 1500$ kopya/ml)

Tablo 5: Mukoza ve zedelenmiş deri teması sonrasında HIV profilaksisi

\begin{tabular}{|l|l|l|l|l|}
\hline \multirow{2}{*}{ Temas Niteliği } & \multicolumn{4}{|c|}{ Kaynak } \\
\cline { 2 - 5 } & HIV (+)/1. Sınıf & HIV (+) / 2. Sınıf ${ }^{3}$ & HIV durumu bilinmiyor & HIV (-) \\
\hline Hafif $^{1}$ & 2 ilaç ile TSP* & 2 ilaç ileTSP & TSPönerilmez & TSPgerekmez \\
\hline Yoğun $^{2}$ & 2 ilaç ileTSP & $\geq 3$ ilaç ileTSP & TSPönerilmez† & TSPgerekmez \\
\hline
\end{tabular}

* TSP: Temas sonrası profilaksi

† Yüksek riskli kaynaktan maruziyet söz konusuysa iki ilaç ile TSP verilebilir

1 Birkaç damla kan vb. küçük miktar ile temas

2 Kanın dökülmesi vb. büyük miktar ile temas

3 Asemptomatik HIV enfeksiyonu veya düșük viral yük (<1500 kopya/ml)

4 Semptomatik HIV enfeksiyonu, AIDS, akut serokonversiyon, yüksek viral yük ( $\geq 1500$ kopya/ml)

\section{Kırım Kongo Kanamalı Ateși Virüsü}

Endemik bölgelerde yaşayan, tarım ve hayvancilikla uğraşan kişiler Kırım Kongo Kanamalı Ateşi (KKKA) açısından majör risk grubunu oluştururken, sağlık çalışanları ikinci sirada yer almaktadır. Bulgaristan'da 1953 ve 1965 y1llar1 arasindaki salgından sonra \%52 ölüm oranıla 42 nozokomiyal olgu saptanmıştır. Bugüne kadar Pakistan, Dubai, Irak, Güney Afrika, Arnavutluk, Moritanya, İran ve Türkiye'den sağlik çalışanları arasında mesleksel KKKA enfeksiyonu bildirilmiștir. Türkiye'de son sekiz yıl içinde yaklaşık 30 sağlık çalışanı enfekte olmuş ve bunların beşi yaşamını kaybetmiştir (35).

Sağlık çalışanlarına KKKA bulaşı ve buna bağlı ölüm oranları popülasyondaki salgınlar ile paralellik 
gösterir (36). Maruziyet sonrası enfeksiyon gelişme riski, temasın şekliyle de ilişkilidir. Bir hastane salginında enfekte kana temas eden sağlık çalışanlarının \%8,7'sinde, kesici-delici alet ile yaralananların \%33’ünde KKKA geliştiği bildirilmiştir (37). KKKA virüsü yüksek mortaliteli nozokomiyal salginlara neden olur ve en yüksek riskli bulaş yolu perkütan maruziyettir. Özellikle tanı almamış hastalarda gastrointestinal kanamaya müdahale ve acil cerrahi girișimler gibi kanamalı hastaların bakımlarını yapmak yüksek risk oluşturmaktadır. KKKA olup da kanama şikayeti ile gelen bu hastalar s1klikla operasyondan sonra tan1 almakta ve operasyon sırasında işlemi gerçekleştiren ekibin yaralanmaları gözden kaçabilmektedir. Kanamalı hastayla temasta basit bariyer önlemlerinin alınması (eldiven, uzun önlük, maske ve gözlük) bulaşı azaltmada son derece etkilidir (38).

Maruziyet sonrası profilaksi, esas olarak yüksek risk grubundaki kişilerde düşünülmelidir. Enfekte hastaların kan ve vücut sıvıları ile temas eden sağlık çalışanlarının, temastan sonra 14 gün boyunca günlük tam kan ve biyokimya testleriyle takip edilmeleri ve gerektiğinde oral ribavirin profilaksisine başlanması önerilmektedir. Ribavirin özellikle hastalığın ilk evrelerinde etkilidir, klinik veriler kanama bașladıktan sonra ilacın etkili olmadığını göstermektedir (39).

Yaklaşık 30 y1l önce, KKKA enfeksiyonunun endemik olduğu bir bölgede sağlık çalışanları ve ordu

\section{KAYNAKLAR}

1. Sepkowitz KA, Eisenberg L. Occupational deaths among healthcare workers. Emerg Infect Dis 2005; 11:1003-8.

2. Haagsma JA, TariqL, Heederik DJ, Havelaar AH. Infectious disease risks associated with occupational exposure: a systematic review of the literature. Occup Environ Med 2012;69:140-146. personeli arasında bir aşılama programı uygulanmış, bu uygulama sonucunda olguların ve ölüm oranının azaldığı bildirilmiş olmakla birlikte; deneyim belirli bir dönem ve bir ülke ile sınırlı kalmış, uluslararası rutin kullanıma yönelik bir aşı henüz piyasaya sunulmamıştır (39).

\section{Fikse Edilmiș İnsan Kadavralarındaki Enfektif Ajanlar}

Diğer sağlık çalışanları gibi anatomi departmanında çalışan sağlık personeli de kadavra kaynaklı enfeksiyon riskine sahiptir. Kadavra dokularının transplantasyon materyali olarak kullanımı, içerebilecekleri patojenik organizmalar nedeniyle sıklıkla kısıtlanmaktadır. Enfeksiyon riski olușturan mikroorganizmalar arasinda Mycobacterium tuberculosis, hepatit B ve C virüsleri, HIV ve prionlar yer almaktadır (40).

Enfekte bir kadavra fikse edildikten en az 24-48 saat sonrasina kadar canlı tüberküloz basili taşyabilmektedir. Fiksatiflerin tüberküloz ile enfekte doku için dezenfeksiyon özellikleri belirsizliğini korumaktadır (40).

Kadavra doku bankalarında $\mathrm{HBs}$ Ag pozitifliği $\% 18,1$ ve anti-HCV pozitifliği ise $\% 14,3$ olarak bildirilmiştir. Ölümden sonra $2^{\circ} \mathrm{C}^{\prime} \mathrm{de}$ saklanan kadavralarda 16 güne kadar plevra sivis1, perikardiyal siv1 ve kanda; en az postmortem altınc1 güne kadar dalak, beyin, kemik iliği ve lenf nodlarında enfeksiyöz HIV varlığ1 bildirilmiştir (43). HIV'e karşı \%25 etanol ve \%0,5 formaldehitin etkili olduğu bir çalıșmada gösterilmișse de, kadavralarda bu konsantrasyonların efektif olup olmadığı net değildir (40).

Kadavradan yapılan hipofiz kaynaklı hormon enjeksiyonlar1, dural greftler veya kornea transplantasyonları prion hastalıkları açısından risklidir. Prion hastalıkları formalinize dokularda canlılıklarını kaybetmemektedir; bu nedenlerle çalışlan tüm kadavralar enfeksiyöz olarak değerlendirilmelidir (40).

Düzenli eğitim programlarının uygulanmas1, kişisel koruyucu ekipmanların kullanımı ve hijyenik uygulamalar ile kadavra çalışmalarında güvenilir çalışma şartları oluşturul-malıdır. Kadavra ile çalışan tüm sağlık personeli hepatit B ve tüberküloza karşı aşılanmalıdır (40).

\section{Sonuç ve Öneriler:}

Sağlık calışanlarının meslek sağlığını korumak için düzenli ve sürekli çalışacak komiteler kurulmalıdır. Bu komitelerce sağlık çalışanlarının ve hastaların korunması için optimal tıbbi bakımı verecek gerekli bilgi, ekipman ve aletler sağlanmalıdır. Mesleki olarak edinilen HIV, HBV ve $\mathrm{HCV}$ enfeksiyonlarının daha sistematik sürveyansları yapilarak, kanla temasın epidemiyolojik tanımlanmaları ortaya çıkarılmalıdır. Ayrica, temas sonrasi profilaksinin erken ve etkin bir şekilde yapılmasına özen gösterilmelidir.
3. Wedum AG. History \& epidemiology of laboratory-acquired infections (in relation to the cancer research program). I Am Biol Safety Assoc 1997;2:12-29.

4. Sağılı Çalışanlarının Sağlı̆̆ Çalışma Grubu. http://www.saglikcalisanisagligi. org (Erişim tarihi: 10.10.2014)

5. Azap A, Ergönül $O$, Memikoğlu KO, Occupational exposure to blood and body fluids among healthcare workers in Ankara, Turkey. Am J Infect Control 2005;33:48-52.
6. Puro V, De Carli G, Cicalini S, European Occupational Post-Exposure Prophylaxis Study Group. European recommendations for the management of healthcare workers occupationally exposed to hepatitis B virus and hepatitis C virus. Euro Surveill 2005;10:260-4.

7. Prüss-Ustün A, Rapiti E, Hutin Y. Estimation of the global burden of disease attributable to contaminated sharps injuries among health-careworkers. Am J IndMed 2005;48: 482-490. 
8. Hacettepe Üniversitesi İş Sağllğ̣ ve Güvenliği Meslek Hastalıklar Uygulama ve Araştırma Merkezi (HISSAM). http://www.hisam.hacettepe.edu.tr (Erişim tarihi: 22.04.2014)

9. Smith DR, Leggat PA. Issues and Innovations in Nursing Practice. Needlestick and sharps injuries among nursing students. J Adv Nurs 2005;51: 449-455.

10. Centers for Disease Control and Prevention. Updated U. S. PublicHealth Service guidelines for the management of occupational exposures to $\mathrm{HBV}, \mathrm{HCV}$, and HIV and recommendations for post exposure prophylaxis. MMWR Morb Mortal Wkly Rep 2001;50:1-52.

11. Türkistanlı E, Şenuzun FE, Karaca BS, San AT, Aydemir G. Ege Üniversitesi Tip Fakültesi Araştırma ve Uygulama Hastanesinde sağlık çalışanlarının bağışıklanma durumu. Ege Tip Derg 2000;39:29-32.

12. Tekin-Koruk S, Koruk İ, Şahin M, Duygu F. Şanlıurfa'da ağız ve diş sağllğı çalışanlarında $\mathrm{HBsAg}$, anti-HBs ve antiHCV pozitifliği ve risk faktörlerinin değerlendirilmesi. Klimik Derg 2009;22:55-61.

13. Tabak F, Balık I, Tekeli E (ed). Viral Hepatit. 2007; 9-50.

14. T.C. Sağlık Bakanlığı Temel Sağlık Hizmetleri Genel Müdürlüğü, Genişletilmiş Bağışıklama Programı Genelgesi. Say1: B100TSH0110005. Tarih: 13.03.2009/7941

15. Ergönül Ö. Sağlık çalışanlarının enfeksiyon riskleri ve korunma yollar1. Klinik Gelişim Dergisi 2007;20:86-98

16. Poland GA, Jacobson RM. Prevention of hepatitis B with the hepatitis B vaccine. N Engl J Med 2004;351:2832-2838.

17. Baxter D. Specific immunization issues in the occupational healthsetting. Occupational Med 2007;57:557-563.

18. Tang Z, Yang D, Hao L, Detection and significance of HCV RNA in saliva, seminal fluid and vaginal discharge in patients with hepatitis C. J Tongji Med Univ 1996;16:11-24.

19. Puro V, Petrosillo N, Ippolito G. Risk of hepatitis C seroconversion after occupational exposures in healthcare workers. Italian Study Group on Occupational Risk of HIV and Other Bloodborne Infections. Am J Infect Control 1995;23:273-7.

20. Yazdanpanah Y, De Carli G, Migueres B, et al. Risk factors for hepatitis $\mathrm{C}$ virüs transmission to healthcare workers after occupational exposure: a European casecontrol study. Clin Infect Dis. 2005; 41(10): 1423-30

21. Kamili S, Krawczynski K, Mc Caustland K, Li X, Alter MJ. Infectivity ofhepatitis $\mathrm{C}$ virus in plasma after drying and storing at room temperature. Infect Cont Hosp Epidemiol 2007;28:519 24.

22. Polish LB, Tong MJ, Co RL, Coleman PJ, Alter MJ. Risk factors for hepatitis C virus infection among healthcare personnel in a community hospital. Am J Infect Control 1993;21:196-200.

23. Ozsoy MF, Oncul O, Cavuslu S, Seroprevalences of hepatitis B and C among healthcare workers in Turkey. J Viral Hepat 2003;10:150-6.

24. FitzSimons D, François G, De Carli G, et al. Hepatitis $B$ virus, hepatitis $C$ virus and other blood-borne infections in healthcare workers: guidelines for prevention and management in industrialised countries. Occup Environ Med. 2008;65:446-51.

25. Alter MJ. Occupational exposure to hepatitis C virus: A dilemma. Infect Control Hosp Epidemiol 1994;15:742-4.

26. Centers for Disease Control and Prevention. Trends in Tuberculosis: MMWR Morb Mortal Wkly Rep 2008; 57;281-285

27. Deuffic-Burban S, Abiteboul D, Lot F, et al. Costs and cost-effectiveness of different follow-up schedules for detection of occupational hepatitis C virus infection. Gut 2006;58:105-110.

28. Charles PGP, GraysonML, AngusPW, SasadeuszJJ. Management of healthcare workers after occupational exposure to hepatitis C virus. Med J Aust 2003;179:153-157.

29. Kamal SM, Fouly AE, Kamel RR, et al. Peginterferon alfa-2b therapy in acute hepatitis C: impact of onset of therapy on sustained virologic response. Gastroenterol. 2006;130:632-8.
30. Hamlyn E, Easterbrook P. Occupational exposure to HIV and the use of postexposure prophylaxis. Occup Med (Lond) 2007;57:329-36

31. Albayrak F, Balık İ.Nozokomiyal viral enfeksiyonlar. Hastane İnfeks Derg 2000; 4: 16-23.

32. Gerberding JL. Clinical practice. Occupational exposure to HIV in healthcare settings. N Engl J Med 2003;348:826-33.

33. Wnuk AM. Occupational exposure to HIV infection in healthcare workers. Med Sci Monit. 2003;9:197-200.

34. Centers for Disease Control and Prevention. Updated U.S. Public Health Service Guidelines for the Management of Occupational Exposures to HIV and Recommendations for Postexposure Prophylaxis. MMWR Morb Mortal Wkly Rep 2005; 54(RR-9):1-17.

35. Tarantola A, Ergonul O, Tattevin P. Estimates and prevention of CrimeanCongo Hemorrhagic Fever risks for healthcare workers In. Ergonul O, Whitehouse CA, eds. Crimean-Congo Hemorrhagic Fever:A Global Perspective. Dordrecht (NL): Springer, 2007: 281-294.

36. Pullukcu H. Hastane personelinin nozokomiyal enfeksiyonlardan korunmasi. Sağlıkta Birikim Derg 2007;1: 58-64

37. Ergonul O. Crimean-Congo haemorrhagic fever review. Lancet Infect Dis 2006; 6:203-14

38. Ergönül O, Celikbaș A, Dokuzoğuz B, et al. Characteristics of patients with Crimean-Congo hemorrhagic fever in a recent outbreak in Turkey and impact of oral ribavirin therapy. Clin Infect Dis 2004;39:284-7.

39. Ergonul O. Treatment of CrimeanCongo Hemorrhagic Fever. In: Ergonul O, Whitehouse CA, eds. Crimean Congo Hemorrhagic Fever: A Global Perspective. Dordrecht (NL): Springer; 2007:245-60.

40. Demiryurek D, Bayramoglu A, Ustacelebi $S$. Infective agents in fixed human cadavers: A brief review and suggested guidelines. The Anatomical Record (New Anat)2002;269:194-197. 
